\title{
Kultura informacji osób z niepełnosprawnością wzroku w refleksji tyflologiczno-informatologicznej
}

\begin{abstract}
Małgorzata Czerwińska, Kultura informacji osób z niepetnosprawnościa wzroku w refleksji tyflologiczno-informatologicznej [Information culture of persons with visual disabilities in typhlology and information science reflections]. Interdyscyplinarne Konteksty Pedagogiki Specjalnej, nr 18, Poznań 2017. Pp. 33-57. Adam Mickiewicz University Press. ISSN 2300-391X

The subject of this paper is the specificity of the information space of persons with visual disabilities as a component of their information culture, according to the concept proposed by M. Kisilowska. Based on systematic analysis of documents and long years of participative observations, the deliberations focus on legal solutions governing the access of persons with visual disabilities to information, the navigation and cognition spheres of a blind information user and the specificity of providing information, in particular the Braille system, tactile graphics, audio description, alternative materials and augmentative technologies. The deliberations highlight obstacles in accessing information by persons with visual disabilities and suggest both practical solutions and research proposals for a complex analysis of the information culture of persons with visual disabilities in Poland.
\end{abstract}

KEY WORDS: information culture, person with visual disabilities, Braille system, tactile graphics, audio description, alternative materials, augmentative technologies 


\section{Wprowadzenie}

Znamienne dla społeczeństwa informacyjnego jest zaawansowanie technologii informacyjno-telekomunikacyjnych, stwarzające warunki do powszechnego wykorzystania informacji w produkcji wyrobów i świadczenia usług. Zakłada się, że społeczeństwo informacyjne zapewnia obywatelom dostęp i umiejętność korzystania $\mathrm{z}$ technologii teleinformatycznych $\mathrm{w}$ celu podnoszenia i aktualizacji wiedzy, wykonywania pracy zawodowej, uczestniczenia w kulturze, ochrony zdrowia, wypełniania wolnego czasu i innych usług wpływających na jakość życia ${ }^{1}$. Właściwością tegoż społeczeństwa jest kult wiedzy naukowej i informacji, kultury audiowizualnej oraz dążenie do upowszechnienia dostępu do technologii informacyjnokomunikacyjnych i cyberprzestrzeni. Niestety, społeczeństwo informacyjne generuje grupy wykluczone cyfrowo.

Za Dominikiem Batorskim należy zauważyć, że:

wykluczenie cyfrowe (e-wykluczenie) to różnice między tymi, którzy mają regularny dostęp do technologii cyfrowo-informacyjnych i potrafią efektywnie z nich korzystać, a tymi, którzy tego dostępu i umiejętności nie mają ${ }^{2}$.

Wykluczenie cyfrowe jest przyczyną i konsekwencją wykluczenia społecznego, rozumianego jako:

sytuacja uniemożliwiająca lub znacznie utrudniająca jednostce lub grupie, zgodne $\mathrm{z}$ prawem pełnienie ról społecznych, korzystanie z dóbr publicznych i infrastruktury społecznej, gromadzenie zasobów i zdobywanie dochodów w godny sposób ${ }^{3}$.

${ }^{1}$ Główny Urząd Statystyczny, Społeczeństwo informacyjne w Polsce. Wyniki badań statystycznych z lat 2004-2006, Warszawa 2008, s. 7.

2 D. Batorski, Wykluczenie cyfrowe w Polsce, "Studia Biura Analiz Sejmowych Kancelarii Sejmu" 2009, nr 3(19), s. 225-226.

${ }^{3}$ Ministerstwo Polityki Społecznej, Zespół Zadaniowy ds. Reintegracji Społecznej, Narodowa Strategia Integracji Społecznej dla Polski, Warszawa 2004, http:/ /www. mpips.gov.pl/userfiles/File/mps/NSIS.pdf, s. 23 [dostęp: 15.11.2016]. 
Wśród grup wykluczonych społecznie i cyfrowo wymienia się m.in. osoby z niepełnosprawnością.

Tymczasem $\mathrm{w}$ przypadku tych osób nowe technologie nie tylko generują i utrwalają, ale też redukują nierówności społeczne. Osobom z niepełnosprawnością wzroku ewidentnie poszerzają dostęp do informacji, przeobrażając jakościowo ich, powodowaną dysfunkcją sensoryczną, niesprawność czytelniczą. Wprowadzają do kultury informacji, rozumianej za Małgorzatą Kisilowską jako „sposób świadomego i aktywnego funkcjonowania człowieka w przestrzeni informacyjnej oraz jego konsekwencje"4.

Dla kształtowania się kultury informacji kluczowymi aspektami są: indywidualne kompetencje informacyjne jako warunek konieczny jej rozwoju oraz środowisko informacyjne jako otoczenie, do funkcjonowania w którym wzmiankowane kompetencje są niezbędne.

Kompetencje informacyjne $w$ dużej mierze wyznaczają człowiekowi ( $w$ tym $z$ niepełnosprawnością) miejsce $w$ stratyfikacji społeczeństwa informacyjnego, lokując go w klasie proletariatu, kogitariatu lub dygitariatu 5 .

W której z wymienionych klas znajdują się osoby z niepełnosprawnością wzroku? Jaka jest ich świadomość i aktywność informacyjna? Czym charakteryzują się informacyjne kompetencje? Pytania powyższe inspirują do rozległych badań informatologicznotyflologicznych, których niniejsze opracowanie jest zapowiedzią, ograniczając się do refleksji nad specyfiką przestrzeni informacyjnej osób z niepełnosprawnością wzroku.

Pod pojęciem "przestrzeni informacyjnej” rozumieć należy: „wielowymiarowy, dynamiczny, otwarty zbiór treści (danych i informacji), ich nośników oraz użytkowników"6, zbudowany z materialnych artefaktów informacyjnych (nośniki, urządzenia) i artefaktów niematerialnych (język, zachowania - artefakty behawioralne).

\footnotetext{
${ }^{4}$ M. Kisilowska, Kultura informacji, Wydawnictwo SBP, Warszawa 2016, s. 42.

${ }^{5}$ R. Tadeusiewicz, Społeczność Internetu, Akademicka Oficyna Wydawnicza „Exit”, Warszawa 2002, s. 285.

${ }^{6}$ M. Kisilowska, op. cit.
} 
Opierając się na analizie dokumentów i obserwacji uczestniczącej, rozważania skoncentrowano na rozwiązaniach prawnych dostępu osób z niepełnosprawnością wzroku do informacji, uwarunkowaniach sfery orientacyjno-poznawczej niewidzącego użytkownika informacji, specyfice udostępniania informacji, ze szczególnym uwzględnieniem systemu Braille'a, tyflografiki, audiodeskrypcji, materiałów alternatywnych i technologii wspomagających.

\section{Uregulowania prawne dostępu do informacji i ich realizacja}

Dostęp do informacji osób z niepełnosprawnością (w tym niepełnosprawnością wzroku) reguluje wiele międzynarodowych i krajowych aktów prawnych. Spośród uregulowań międzynarodowych, przywołać tu przede wszystkim należy Konwencję Praw Osób Niepełnosprawnych Narodów Zjednoczonych, ustanowioną w 2006 r., a ratyfikowaną przez Polskę w 2012 r. Jej art. 9 zobowiązuje do działań na rzecz dostępności, na równych zasadach z innymi obywatelami, do środowiska fizycznego, transportu, informacji i komunikacji międzyludzkiej, w tym technologii i systemów komunikacyjnych i informacyjnych oraz do innych udogodnień i usług (m.in.: informacyjnych, komunikacyjnych, elektronicznych), oferowanych całemu społeczeństwu poprzez m.in.: zapewnienie oznakowania w alfabecie Braille'a oraz w formie łatwej do czytania i zrozumienia w budynkach i innych obiektach publicznych, zapewnienie pomocy ze strony innych osób i pośredników (np. przewodników, lektorów), promowanie dostępu do najnowszych technologii oraz systemów informacyjno-komunikacyjnych, w tym do internetu.

Art. 21, odnoszący się do wolności wypowiedzi i swobody wyrażania poglądów oraz dostępu do informacji, zaleca m.in.: dostarczanie osobom niepełnosprawnym informacji przeznaczonych dla ogółu społeczeństwa w dostępnym formacie i za pomocą środków 
przekazu odpowiednich do rodzaju niepełnosprawności, bez opóźnień i dodatkowych kosztów, akceptowanie i umożliwienie korzystania w sytuacjach oficjalnych z pisma Braille'a, wspomagających i alternatywnych sposobów komunikacji oraz wszelkich innych środków, sposobów i formatów komunikacji wybranych przez osoby niepełnosprawne, nakłanianie prywatnych usługodawców świadczących usługi dla ogółu społeczeństwa, w tym dostawców usług internetowych, aby dostarczali informacje i usługi w formie dostępnej i przydatnej dla osób niepełnosprawnych, zachęcanie środków masowego przekazu, w tym dostawców informacji poprzez internet, aby udostępniały swoje usługi osobom niepełnosprawnym.

Art. 24, poświęcony prawu do edukacji włączającej, zaleca m.in.: umożliwienie nauki alfabetu Braille'a, pisma alternatywnego, stosowanie powiększonego druku, wspomagających i alternatywnych sposobów, środków i formatów komunikacji.

Art. 30 podnosi prawo do uczestniczenia w życiu kulturalnym, zapewniane poprzez m.in.: korzystanie $\mathrm{z}$ materiałów dotyczących zagadnień kultury w dostępnych formatach, dostęp do programów telewizyjnych, filmów, teatru i innych form działalności kulturalnej w dostępnych formatach, zapewnienie, aby akty prawne dotyczące ochrony praw własności intelektualnej nie stanowiły nieracjonalnej bariery dyskryminującej osoby niepełnosprawne $\mathrm{w}$ dostępie do materiałów związanych ze sferą kultury7.

Szansą na szerokie udostępnienie publikacji książkowych i prasy jest Traktat z Marrakeszu o ułatwieniu dostępu do opublikowanych utworów osobom niewidomym, słabowidzącym i osobom z niepełnosprawnościami uniemożliwiającymi zapoznawanie się z drukiem, Wypracowany przez Światową Organizację Własności Intelektualnej (agenda ONZ), ogłoszony w 2013 r., podpisany przez stronę polską 2014 r. Jego celem jest ustanowienie międzynarodowego standardu korzystania przez osoby z niepełnosprawnością $\mathrm{z}$ utworów publikowanych w postaci druku i pozostających pod

${ }^{7}$ Konwencja Praw Osób Niepełnosprawnych, http://www.unic.un.org.pl/do kumenty/Konwencja_Praw_Osob_Niepelnosprawnych.pdf [dostęp: 14.12.2016]. 
ochroną prawa (pozwolenie na wytwarzanie i upowszechnianie publikacji w wersjach alternatywnych) ${ }^{8}$.

Zasadność postanowień Traktatu została potwierdzona zapisami Rezolucji zwiększającymi dostęp osób niewidomych i słabowidzących do publikacji drukowanych, wydanymi przez Komisję ds. konstytucyjnych (AFCO) Parlamentu Europejskiego w 2017 r. ${ }^{9}$.

Dostępnością internetu dla osób $\mathrm{z}$ niepełnosprawnością od 1994 r. zajmuje się WORLD VIDE WEB CONSORTIUM - W3C zrzeszenie ponad czterystu organizacji, firm, agencji rządowych i uczelni z całego świata. Wypracowane przez nie standardy stały się podstawą regulacji prawnych w wielu krajach, w tym także w Polsce. Od 2008 r. obowiązuje, opracowany przez Web Accessibility Initiative (WAI), międzynarodowy standard WCAG 2.0 (Web Content Accessibility Guidelines), wraz z dokumentami uzupełniającymi: Understanding WCAG, Techniques for WCAG ${ }^{10}$.

W Polsce proces regulacji dostępności stron internetowych rozpoczął się w 2010 r. od przyjęcia nowelizacji ustawy o informatyzacji działalności podmiotów realizujących zadania publiczne. Zawarto $\mathrm{w}$ niej zobowiązanie do określenia sposobu udostępniania treści niepełnosprawnym obywatelom ${ }^{11}$.

Stosowne zapisy znajdują się również w Rozporządzeniu Rady Ministrów z dnia 12 kwietnia 2012 r. w sprawie Krajowych Ram Interoperacyjności, minimalnych wymagań dla rejestrów publicznych i wymiany informacji $\mathrm{w}$ postaci elektronicznej oraz minimal-

8 Traktat z Marrakeszu, http://www.prawoautorskie.gov.pl/.../Traktat_z_ Marrakeszu_-_polska_wersja_jezykowa_finalna.pdf [dostęp: 5.05.2017].

${ }^{9}$ Rezolucja Komisji ds. konstytucyjnych (AFCO) Parlamentu Europejskiego, http:/ / www.infor.pl/.../754032,Lepszy-dostep-do-ksiazek-i-prasy-dla-niewidomychi-slabowidzacych.html [dostęp: 5.05.2017].

${ }^{10}$ M. Gajda, WCAG 2.0 w skrócie - 25 najważniejszych zasad, http://dostepne strony.pl/artykul/753 [dostęp: 21.11.2016]; A. Marcinkowski, P. Marcinkowski, WCAG 2.0. Podręcznik dobrych praktyk, http://widzialni.org/wcag-20-podrecznik-dobrychpraktyk,m,mg,5,51 [dostęp: 12.01.2015].

11 Ustawy o informatyzacji działalności podmiotów realizujących zadania publiczne, http:/ / www.isap.sejm.gov.pl/Download?id=WDU20050640565\&type=3 [dostęp: 5.05.2017]. 
nych wymagań dla systemów teleinformatycznych ${ }^{12}$. Rozporządzenie nakłada na wszystkie instytucje publiczne oraz jednostki realizujące działania publiczne obowiązek zagwarantowania dostępności swoich stron internetowych do końca 2015 r., na poziomie AA. Wytycznych WCAG 2.0.

Raporty alternatywne organizacji pozarządowych ${ }^{13}$, monitorowanie i audyty organizacji zrzeszonych w Forum Dostępnej Cyberprzestrzeni (np. Fundacja „Widzialni”), a także doświadczenia autorki wskazują na niską znajomość wzmiankowanych uregulowań przez zleceniodawców i twórców stron internetowych.

Przestrzeń informacyjną osób z niepełnosprawnością wzroku w Polsce cechuje zatem: nieprzestrzeganie standardów WCAG 2.0. przy tworzeniu stron internetowych, dominacja papierowego obiegu dokumentów zapisanych w tradycyjnym druku (tzw. czarnodrukowych), znikoma liczba programów telewizyjnych i filmów $\mathrm{z}$ audiodeskrypcją, niedostateczne wyposażenie szkół ogólnodostępnych $\mathrm{w}$ technologie wspomagające edukację uczniów $\mathrm{z}$ niepełnosprawnością wzroku, niedostateczna liczba podręczników szkolnych adaptowanych do możliwości percepcyjnych uczniów z niepełnosprawnością wzroku, brak właściwych kompetencji nauczycieli szkół ogólnodostępnych do pracy z uczniami z niepełnosprawnością wzroku z wykorzystaniem wydawnictw alternatywnych i tech-

12 Rozporządzenie Rady Ministrów z dnia 12 kwietnia 2012 r. w sprawie Krajowych Ram Interoperacyjności, minimalnych wymagań dla rejestrów publicznych i wymiany informacji w postaci elektronicznej oraz minimalnych wymagań dla systemów teleinformatycznych, http://www.isap.sejm.gov.pl/DetailsServlet?id= WDU20120000526 [dostęp: 5.05.2017].

13 Dostępność witryn internetowych instytucji publicznych dla osób niepetnosprawnych. Ocena zgodności z międzynarodowym standardem WCAG 2.0 oraz polskimi regulacjami prawnymi, red. M. Dziwisz, P. Witek, Kraków 2013; D. Paszkiewicz, J. Dębski, Dostępność serwisów internetowych. Dobre praktyki w projektowaniu serwisów internetowych dostępnych dla osób z różnymi rodzajami niepetnosprawności, Warszawa 2013; Wykorzystanie technologii informacyjno-komunikacyjnych w aktywizacji osób niepetnosprawnych, red. B. Mioduszewski, Fundacja "Aktywizacja”, Warszawa 2013; Społeczny Raport Alternatywny z realizacji Konwencji o prawach osób z niepełnosprawnościami w Polsce, red. J. Zadrożny, Fundacja KSK, Warszawa 2015. 
nologii wspomagających, znikome wykorzystanie nowych technologii (np. tyflografika, audiodeskrypcja) w udostępnianiu dóbr kultury, nieprzestrzeganie przez wydawców zaleceń odnoszących się do udostępniania publikacji w formatach alternatywnych.

\section{Kognitywny proces odbioru informacji przez osoby z niepełnosprawnością wzroku}

Percepcja i recepcja informacji przez osoby z niepełnosprawnością wzroku wyznaczana jest zjawiskiem przeciążenia (przeładowania) informacyjnego, typowym dla kognitywnego proces zachowania się człowieka informacyjnego ${ }^{14}$ oraz specyfiką sfery orientacyjno-poznawczej osoby niewidzącej.

Procesy poznawcze wzmiankowanych osób cechują się: polisensorycznym sposobem postrzegania, złożonym z bodźców: dotykowych, słuchowych, węchowych, smakowych; kompensacją poznawczą (kognitywną) na poziomie sensorycznym i percepcyjnym - tłumaczoną teorią tworzenia się dynamicznych układów strukturalnych w obrębie I i II układu sygnałowego ${ }^{15}$; dotykowymi i polisensorycznymi schematami poznawczymi; wyobrażeniami surogatowymi; poznawczą i kompensacyjną rolą języka (mowy) ${ }^{16}$.

Podstawowymi „kanałami informacyjnymi” są dotyk i słuch. Zauważyć należy, że dotyk nie ma łatwości wzroku w percepowa-

14 W. Babik, O natłoku informacji $i$ związanym z nim przeciązeniu informacyjnym, http:/ / www.ktime.up.krakow.pl/ref2010/babik.pdf [dostęp: 31.04.2015]; Z. Melosik, Mass media, tożsamość i rekonstrukcje kultury wspótczesnej, [w:] Media - Edukacja Kultura, red. W. Skrzydlewski, S. Dylak, Polskie Towarzystwo Technologii i Mediów Edukacyjnych, Rzeszów - Poznań 2012, s. 32-49; I. Rotberg, W morzu informacji, http://www.psychologia-spoleczna.pl/ porady/1506-w-morzu-informacji.html [dostęp: 15.01.2015].

${ }_{15}$ M. Grzegorzewska, Wybór pism, PWN, Warszawa 1964.

16 T. Majewski, Tyflopsychologia rozwojowa: Psychologia dzieci niewidomych i stabo widzacych, PZN, Warszawa 2002; M. Czerwińska, Niewidomy, [w:] Encyklopedia pedagogiczna XXI wieku, t. 3: M-O, red. T. Pilch, Wydawnictwo Akademickie "Żak", Warszawa 2004, s. 685-693. 
niu linii ciągłej, gdyż jest zmysłem wrażeń przerywanych. Percepcja dotykowa powierzchni jest trudniejsza niż punktów wypukłych. Zakres uwagi jest ograniczony: liczba elementów prostych, percepowanych w jednym akcie postrzegania nie może przekroczyć sześciu. Łatwiej postrzegane są wrażenia uporządkowane niż bezładne. Dotyk odbiera wrażenia: twardość, miękkość, gładkość, szorstkość. Pozwala poznać wielkość i kształt (niedokładnie). Jest zmysłem sekwencyjnym (wrażeń sukcesywnych). Jest kontaktozmysłem (zmysł bliskonośny), detekcyjnym, skórnym (obok zmysłu temperatury i bólu). Dzieli się na bierny i czynny (zmysł dotykowo-ruchowy), dzięki czemu pozwala na odbiór cech przedmiotu: szorstkość, gładkość, elementarne cechy przestrzenne (długość, szerokość, wysokość, kierunek), wielkość i kształt.

Dotyk reaguje obronnością dotykową na "przedawkowanie" stymulacji dotykowej ${ }^{17}$.

Równie istotne znaczenie poznawcze ma zmysł słuchu: służy lokalizacji dźwięku, wspomaga rozwój mowy, jest źródłem informacji (instrukcji) słownej, dostarcza informacji o nastroju, charakterze, osobowości, wyglądzie fizycznym osób z otoczenia ${ }^{18}$. Umożliwia doznania estetyczne.

Nakreślone tu uwarunkowania poznawcze są powodem trudności z odbiorem, przetwarzaniem i efektywnym wykorzystywaniem informacji. Rodzą tym samym potrzebę stosowania materiałów w formatach alternatywnych i technologii wspomagających.

\section{System Braille'a wobec technologii cyfrowych}

Technika komputerowa zniosła niedoskonałości przypisywane systemowi Braille'a, zmieniając również jego morfologię. W pracy z komputerem system Braille'a stał się tymczasową reprezentacją znaków wyświetlanych na ekranie. Technika komputerowa pozwo-

17 Ibidem.

18 Ibidem. 
liła na pełną korektę tekstu. Umożliwia czytanie systemem Braille'a publikacji przechowywanych na nośnikach cyfrowych, co ma szczególne znaczenie w przypadku wydawnictw wielotomowych. Poprzez towarzyszące komputerowi skaner i drukarkę brajlowską, możliwe jest zwielokrotnione powielenie każdego tekstu „czarnodrukowego" i brajlowskiego. Tradycyjne przesyłki pocztowe tomów brajlowskich zastąpiono transmisją elektroniczną ${ }^{19}$.

Technika cyfrowa doprowadziła do zmiany $w$ budowie systemu Braille'a, czego wyrazem jest współczesna odmiana systemu - EUROBRAILLE, tzw. brajl komputerowy. Jest on oparty na ośmiopunkcie (dwie kolumny po cztery punkty), przy zachowaniu numeracji podstawowych punktów, jak w brajlu standardowym. Kombinacje punktów w brajlu ośmiopunktowym dają 256 różnych znaków. Brajl ośmiopunktowy umożliwia stworzenie specjalnych znaków do zapisu symboli stosowanych w informatyce oraz obsługę elektronicznych urządzeń brajlowskich, np. monitorów i notatników brajlowskich ${ }^{20}$.

System Braille'a, bez względu na postać, ma ogromne znaczenie dla psychospołecznego funkcjonowania niewidomych. Jest kluczem do umiejętności samodzielnego czytania i pisania. Pozwala opanować zasady ortografii, interpunkcji, gramatyki. Umożliwia zapoznanie się $\mathrm{z}$ rozmieszczeniem tekstu na stronie. $\mathrm{W}$ porównaniu z odsłuchiwaniem tekstów, umożliwia czytelnikowi koncentrację na szczegółach i pełniejsze zrozumienie kontekstu treściowego.

Udostępnia różne źródła informacji: tekstowe, matematyczne, muzyczne, informatyczne, tyflograficzne. Zapobiega wtórnemu analfabetyzmowi. Zwiększa niezależność w życiu codziennym. Stwarza równe szanse edukacyjne, zawodowe. Pozwala uczestniczyć w życiu społecznym, naukowym, technicznym, kulturalnym²1.

${ }^{19}$ M. Czerwińska, System Braille'a - rewolucja medialna czy inkluzja społeczna osób z niepetnosprawnościq wzroku?, „Przegląd Biblioteczny” 2015, nr 3, s. 365-381.

${ }^{20}$ Ibidem.

${ }^{21}$ Ibidem; M. Czerwińska, System Braille'a w edukacji i rehabilitacji dzieci z niepetnosprawnością wzroku - przyczynek do komunikacji i inkluzji społecznej, [w:] Edukacyjne 
Szacuje się, że zaledwie 10\% osób pozbawionych wzroku zna i efektywnie wykorzystuje system Braille'a w nauce, pracy, komunikacji oraz dostępie do informacji. Oznacza to, że zdecydowana większość osób niewidomych na świecie nie posługuje się żadnym rodzajem druku. Posługiwanie się w komunikacji pisanej wyłącznie syntezą mowy prowadzi do popełniania błędów językowych, ortograficznych, interpunkcyjnych ${ }^{22}$.

Zatem podejmowany (zwłaszcza przez nauczycieli szkół ogólnodostępnych) dyskurs: system Braille'a czy nowe technologie audialne - jest merytorycznie nieuzasadniony. Edukacja osób niewidzących bez stosowania alfabetu Braille'a prowadzi bowiem do analfabetyzmu. System Braille'a jest podstawą nie tylko alfabetyzacji osób niewidomych, ale także edukacji w obrębie przedmiotów ścisłych. Należy jednak zaznaczyć, że w obliczu rozwoju technologii informacyjno-komunikacyjnych i wspomagających, systemu Braille'a nie można traktować jako jedynego medium komunikacyjnego, lecz wskazane jest edukowanie niewidomych do wykorzystywania zróżnicowanych narzędzi i systemów informacyjno-komunikacyjnych.

\section{Tyflografika a dostęp do informacji}

Powołując się na Marka Jakubowskiego, tyflografikę rozumieć należy, jako:

graficzne odwzorowanie rzeczywistości, użyteczne dla osoby niewidomej lub/i słabowidzącej, wykonane w dostępnej jej konwencji

oblicza komunikacji. Dyskurs interdyscyplinarny, red. J.J. Błeszyński, K.B. Kochan, Uniwersytet Zielonogórski, Zielona Góra 2016, s. 119-134.

${ }_{22}^{2}$ Za: M. Paplińska, Znaczenie czytania dotykowego i jego charakterystyka a bariery mentalne osób niewidomych i ociemniatych wobec pisma Braille'a, [w:] Pismo Braille'a. Z tradycja w nowoczesność, red. M. Paplińska, Fundacja Polskich Niewidomych i Słabowidzących "Trakt”, Warszawa 2016, s. 89-100; E. Śmiechowska-Petrovskij, Integrowanie technologii $i$ technik brajlowskich w edukacji uczniów z niepetnosprawnościa wzroku, [w:] Pismo Braille'a. Z tradycja w..., s. 101-125. 
i skali, zredagowane w sposób umożliwiający i ułatwiający odczytanie dotykiem lub/i słabym wzrokiem przekazywanej grafiką informacji ${ }^{23}$.

O jej wartości informacyjnej decyduje prawidłowo przeprowadzona adaptacja grafiki, czyli proces przeredagowania prezentacji płaskiej do postaci odpowiedniej dla niewidomego/słabowidzącego odbiorcy. Polega on na: zmianie konwencji - sposobu przedstawienia (dla niewidomego niezrozumiała jest np. perspektywa zbieżna i rzut ukośny); zmianie skali (powiększenie obrazu czytelnego dla widzących); zmianie poziomu generalizacji - uszczegółowienia (rezygnacja z mniej istotnych treści); podziale treści ilustracji na kilka prezentacji tego samego obiektu, wykonanych w tej samej lub w innej niż oryginał konwencji (np. zastąpienie prezentacji obiektu w rzucie ukośnym przez kilka prezentacji tego obiektu w rzucie prostokątnym, podział treści mapy na kilka map w jednej lub w różnych skalach); zmianie linii, znaków i kolorów oryginalnego rysunku na zróżnicowane linie, faktury powierzchniowe, inne oznaczenia wypracowane i sprawdzone wcześniej (opracowanie tyflograficzne); poważnym uproszczeniu rysunku do prezentacji czytelnej dotykiem i uzupełnieniu opisem ${ }^{24}$.

Tyflografice przypisuje się istotne miejsce $\mathrm{w}$ przestrzeni informacyjnej osoby z niepełnosprawnością wzroku.

Informuje ona bowiem: o pojęciach przestrzennych (pojęcia geometryczne i z zakresu orientacji), o kształtach przedmiotów (widok, rzut, rzuty, przekrój), o relacjach przestrzennych między przedmiotami (plan, mapa).

Pomaga: poznać i zrozumieć oraz odwzorować pojęcia przestrzenne i rzeczywistość materialną, przekazać informacje o obiek-

${ }^{23}$ M. Jakubowski, Tyflografika - historia $i$ wspótczesność, metody i technologie, "Tyfloświat" 2009, nr 1(3), s. 36-40, http:/ / www.firr.org.pl/uploads/PUB/Tyfloswiat01_2009.pdf [dostęp: 5.05.2017].

24 E. Więckowska, Zasady redagowania tyflografiki, „Tyfloświat” 2009, nr 3(5), s. 7-13, http://www.firr.org.pl/uploads/PUB/Tyfloswiat-03_2009.pdf [dostęp: 5.05.2017]. 
tach i zjawiskach, które nie są możliwe do poznania poprzez bezpośredni ogląd dotykowy (zbyt małe, zbyt delikatne, za duże, niebezpieczne lub poruszają się) $)^{25}$.

\section{Audiodeskrypcja w przestrzeni informacyjnej osób z niepełnosprawnością wzroku}

Jak stwierdza Maryla Hopfinger, audiowizualność:

staje się dla ludzi XXI w. dominującym sposobem orientacji w kulturze. Nie chodzi tu jednak o prymat obrazu nad tekstem, co oznaczałoby odejście od kultury pisma (druku, książki). Kultura współczesna integruje $\mathrm{w}$ audiowizualny syndrom informacje werbalne i niewerbalne, wizualne i audialne, słowne i obrazowe. [...] Audiowizualna kultura nie tylko nie rezygnuje z języka naturalnego, ale jest nie do pomyślenia bez języka jako niewątpliwie głównego kodu kultury ${ }^{26}$.

Stanowisku temu $\mathrm{w}$ pełni odpowiada audiodeskrypcja (AD). Wzbudza ona zainteresowanie nie tylko tyflopedagogów, ale również np. lingwistów, filmoznawców, muzealników, animatorów kultury. Stąd doczekała się już wielu ujęć definicyjnych. W Ustawie o radiofonii i telewizji (1992 r.) definiowana jest jako:

werbalny, dźwiękowy opis obrazu i treści wizualnych zawartych $\mathrm{w}$ audycji audiowizualnej przeznaczony dla osób niepełnosprawnych $\mathrm{z}$ powodu dysfunkcji narządu wzroku, umieszczony $\mathrm{w}$ audycji lub rozpowszechniany równocześnie $\mathrm{z}$ audycją ${ }^{27}$.

Twórcy audiodeskrypcji w Polsce, założyciele białostockiej Fundacji „Audiodeskrypcja” - Barbara Szymańska i Tomasz Strzymiń-

${ }^{25}$ M. Jakubowski, op. cit.; E. Więckowska, Tyflografika - konieczność czasu, [w:] Środowisko Lasek w perspektywie historii i chrześcijańskiej myśli pedagogicznej, red. J. Placha, Wydawnictwo UKSW, Warszawa 2011, s. 283-291.

${ }^{26}$ Nowe media $w$ komunikacji społecznej XX $w$. Antologia, red. M. Hopfinger, Oficyna Naukowa, Warszawa 2005, s. 9-10.

27 Ustawa z dnia 29 grudnia 1992 r. o radiofonii i telewizji, http://www.isap. sejm.gov.pl/DetailsServlet?id=WDU19930070034 [dostęp: 5.05.2017]. 
ski - rozumieją audiodeskrypcję jako przekład treści obrazu na słowa. Werbalny opis warstwy wizualnej spektakli teatralnych, produkcji audiowizualnych, sztuk plastycznych oraz wydarzeń widowiskowych sprawia, iż stają się one dostępne osobom niewidomym i słabowidzącym².

Według Anny Jankowskiej29 i Agnieszki Szarkowskiej ${ }^{30}$ jest to szczególna odmiana tłumaczenia audiowizualnego, dzięki której osoby z deficytem wzroku, otrzymują dostęp do treści odbieranych przez osoby widzące głównie za pomocą narządu wzroku. Audiodeskrypcja jest zatem narracją, przekładem audiowizualnym, przekładem intersemiotycznym, przekładem wewnątrzjęzykowym.

W wyniku intensywnych działań badawczych i praktycznych, wypracowano kilka podstawowych rodzajów audiodeskrypcji:

- audiodeskrypcja w sztukach wizualnych - wykorzystywana w muzeach i galeriach sztuki, zazwyczaj w postaci plików dźwiękowych, dołączanych do przewodników audio - opisuje dzieła z zakresu malarstwa, rzeźby, fotografii czy instalacji; stosowana do opisu architektury, terenu naturalnego;

- audiodeskrypcja na potrzeby ekranu (w filmie, programach telewizyjnych) - występuje jako dodatkowa ścieżka dźwiękowa pomiędzy dialogami, opisywane są elementy wizualne (gra aktorów, kostiumy, barwy i światło, scenografia);

- audiodeskrypcja w przedstawieniach na żywo - w spektaklu teatralnym - odczytywana na żywo, wplatana pomiędzy dialogi aktorów; w operze, na koncertach, na przedstawieniach tanecznych (baletowych);

- audiodeskrypcja widowisk sportowych - różni się od komentarza radiowego szczegółowym opisem lokalizacji zawodników czy opisywaniem tego, co dzieje się na trybunach;

${ }^{28}$ B. Szymańska, T. Strzymiński, Audiodeskrypcja. Obraz stowem malowany. Standardy tworzenia audiodeskrypcji do produkcji audiowizualnych, Fundacja „Audiodeskrypcja", Białystok 2010.

29 A. Jankowska, Audiodeskrypcja - wzniosty cel w ttumaczeniu, „Między oryginałem a przekładem" 2009, R. XIV, s. 225-246.

30 A. Szarkowska, Przekład audiowizualny w Polsce - perspektywy $i$ wyzwania, „Przekładaniec” 2009, nr 1(20), s. 8-25. 
- audiodeskrypcja prasowa (ilustracji prasowej) - stosowana w elektronicznej wersji czasopism;

- audiodeskrypcja w materiałach edukacyjnych - stosowana np. w multimedialnych środkach dydaktycznych ${ }^{31}$.

Informacyjna wartość audiodeskrypcji warunkowana jest jej profesjonalnym przygotowaniem, uwzględniającym zasady: należy dokładnie poznać utwór/obiekt, który będzie opisywany; opis powinien odpowiadać na pytania: kto?, co?, jak?, gdzie?, kiedy?; należy opisywać w myśl zasady - od ogółu do szczegółu; opis ma pobudzać wyobraźnię (używając bogatego słownictwa, porównań, metafor, epitetów); należy zachować obiektywizm (bez wartościowania, komentowania, interpretowania czy cenzurowania); opis musi być spójny, przemyślany i odpowiadać na potrzeby odbiorcy; opis musi być dostosowany do określonej grupy odbiorców, np. dzieci; tekst audiodeskrypcji, przed odtworzeniem przez użytkownika, powinien zostać poddany redakcji i ocenie innego redaktora/konsultanta; jakość nagrania/odczytania tekstu powinna być bardzo dobra ${ }^{32}$.

Zatem prawidłowo przygotowana audiodeskrypcja powinna cechować się zwięzłością (kondensacją), obiektywizmem i neutralnością.

Audiodeskrypcja zrealizowana $\mathrm{z}$ poszanowaniem zasygnalizowanych zasad ma poważne znaczenie dla psychospołecznego funkcjonowania osób z niepełnosprawnością wzroku. Umożliwia bo-

${ }^{31}$ M. Ciborowski, Znaczenie audiodeskrypcji dla niewidomych w Polsce, „Przekładaniec" 2009, nr 20, s. 136-138; A. Walczak, M. Rubaj, Audiodeskrypcja na lekcji historii, biologii i fizyki w klasie uczniów z dysfunkcja wzroku, „Przekładaniec” 2014, nr 28, s. 63-79; K. Krejtz, I. Krejtz, A. Szarkowska, A. Kopacz, Multimedia w edukacji. Potencjał audiodeskrypcji w kierowaniu uwaga wzrokowa ucznia, „Przekładaniec” 2014, nr 28, s. 80-92; A. Sadowska, Audiodeskrypcja do ilustracji w prasie - wskazówki dla trenerów szkolacych audiodeskryptorów, "Przekładaniec” 2014, nr 28 s. 140-152; I. Michalewicz, Audiodeskrypcja po Euro 2012 - zawrotne tempo akcji czy para w gwizdek?, „Przekładaniec" 2014, nr 28, s. 153-162; M. Kalbarczyk, J. Mirowski, Świat opisywany dźwiękiem, Fundacja „Szansa dla Niewidomych”, Warszawa 2015.

32 Ustawa z dnia 25 marca 2011 r. o zmianie ustawy o radiofonii i telewizji oraz niektórych innych ustaw, http://www.isap.sejm.gov.pl/DetailsServlet?id=WDU 20110850459; M. Kalbarczyk, J. Mirowski, Świat opisywany dźwiękiem, Fundacja „Szansa dla Niewidomych”, Warszawa 2015. 
wiem dostęp do wizualnych i audiowizualnych dóbr kultury. Udostępnia edukacyjne produkty audiowizualne (multimedia). Dostarcza opisu przedmiotów i zjawisk niemożliwych do poznania dotykowego. Pomaga w przyswajaniu specjalistycznej terminologii związanej z różnymi dziedzinami nauki - rozwój umiejętności językowych. Stymuluje rozwój sfery orientacyjno-poznawczej (min. uwagi poznawczej, pamięci, wyobraźni). Umożliwia osobom niewidomym i niedowidzącym włączanie się samodzielnie, aktywnie i kompetentnie w życie społeczno-kulturalne. Inspiruje wrażenia estetyczne, umożliwia doświadczanie piękna.

Przykładem profesjonalnie przygotowanych audiodeskrypcji są produkcje Fundacji „Audiodeskrypcja33, „Katarynka” - projekt „Adapter" ${ }^{\prime 2}$, Mazowieckiego Stowarzyszenia Pracy dla Niepełnosprawnych „De Facto” - projekty „E-kiosk” i „Niewidzialna Galeria Sztuki”35.

\section{Wydawnictwa i technologie wspomagające osoby z niepełnosprawnością wzroku}

Materialne artefakty informacyjne obejmują nośniki i urządzenia dostosowane do odbioru i obsługi wynikającej ze specyfiki poznawczej osób z niepełnosprawnością wzroku.

Współczesny repertuar wydawnictw w tzw. formatach alternatywnych uwzględnia: wydawnictwa w systemie Braille'a, wydawnictwa do odbioru wielozmysłowego (np. obrazkowe książki dotykowe, książki brajlo-drukowe), tyflografikę: książki ilustrowane, mapy, plany, makiety, modele, wydawnictwa w systemie W. Moona, wydawnictwa dźwiękowe (analogowa książka mówiona, Digital Talking Books, talking book, audiobook), audiodeskrypcję: audiodeskrybowane filmy fabularne, dokumentalne, audiodeskrypcje do dzieł sztuki, wydawnictwa w druku powiększonym, magnigrafikę, wydawnictwa w zapisie cyfrowym (TXT, RTF, DOC, PDF) i gra-

\footnotetext{
33 http:/ / www.audiodeskrypcja.org.pl/ [dostęp: 7.05.2017].

34 http:/ / www. fundacjakatarynka.pl/ [dostęp: 7.05.2017].

${ }^{35}$ http://www.defacto.org.pl/ [dostęp: 7.05.2017].
} 
ficznym (DJVU), cyfrowe wydawnictwa dźwiękowo-tekstowe (DAISY - Digital Accessible Information System).

Technologie wspomagające/asystujące obejmują: syntezatory mowy, moduły (programy): udźwiękawiające, ubrajlawiające, udźwiękawiająco-ubrajlawiające, powiększające, powiększająco-udźwiękawiające, urządzenia lektorskie, programy lektorskie, monitory brajlowskie, notatniki brajlowskie (z syntezą mowy i monitorem brajlowskim), interaktywne tablety $\mathrm{z}$ modułami dźwiękowymi i dotykowymi, brajlowskie klawiatury komputerowe, drukarki brajlowskie, drukarki 3D, wygrzewarki do tłoczenia tyflografiki, powiększalniki i lupy (elektroniczne), OCR, OBR i programy lektorskie, programy użytkowe: np. do brajlowskiego składu i druku komputerowego, do translacji zapisu nutowego na brajlowską notację muzyczną, brajlowskie maszyny do pisania (mechaniczne i elektroniczne), mówiące słowniki elektroniczne, odtwarzacze książek cyfrowych, dyktafony cyfrowe, organizery, programy udźwiękawiające telefony komórkowe (smartfony).

Wzmiankowane tu wydawnictwa i technologie wspomagające ułatwiają edukację i pracę osób z niepełnosprawnością wzroku, zwiększają możliwości komunikacyjne (w tym komunikację zapośredniczoną) i dostęp do informacji.

\section{Zakończenie}

Wydawnictwa alternatywne, komputer, technologie wspomagające i internet to narzędzia, które mają ogromne znaczenie dla kultury informacji osób niepełnosprawnych wzrokowo. Dzięki nim osoby te korzystają z zasobów informacyjnych i edukacyjnych, nawiązują kontakty, rozwijają kompetencje społeczne, prowadzą aktywność zawodową, wypełniają czas wolny.

Wieloletnie doświadczenia autorki i obserwacja uczestnicząca, potwierdzone wystandaryzowanymi badaniami ${ }^{36}$, wskazują na

${ }^{36}$ Np. http:/ / www.kulturaslepych.farbb.com/ [dostęp: 7.05.2017]; Wykorzystanie technologii informacyjno-komunikacyjnych w aktywizacji osób niepetnosprawnych, red. 
szereg ograniczeń w przestrzeni informacyjnej osób z niepełnosprawnością wzroku. Dotyczą one np.: dostępu do stron internetowych (w wyniku nieprzestrzegania przez ich twórców zasad ustalonych przez Konsorcjum W3C), produkcji i udostępniania wydawnictw $\mathrm{w}$ formatach alternatywnych, możliwości odczytu przez programy typu screen reader plików graficznych oraz multimedialnych wydawnictw informacyjnych (np. słowników i encyklopedii), wsparcia finansowego państwa w zakresie wyposażenia placówek edukacyjnych, bibliotecznych i osób indywidualnych w technologie tyfloinformatyczne, produkcji wydawnictw tyflograficznych i audiodeskrypcji (np. audycje telewizyjne, filmy dokumentalne, dzieła sztuki wizualnej).

Wzmiankowane ograniczenia rodzą postulaty o charakterze praktycznym. Wskazują one m.in. na konieczność: skoordynowania działań na rzecz przygotowywania w formatach alternatywnych literatury naukowej i popularnonaukowej, adaptacji do systemu Braille'a i druku powiększonego podręczników (zwłaszcza do nauki języków obcych i z zakresu nauk ścisłych), wprowadzenia jednolitych zasad redagowania i adaptowania grafiki do możliwości odczytu przez osoby niewidome, prowadzenia internetowego ogólnopolskiego katalogu dostępnych w kraju materiałów tyflograficznych, ścisłej współpracy bibliotek, wydawców, organizacji pozarządowych, placówek edukacyjnych - na rzecz powszechności i wysokiego poziomu usług biblioteczno-informacyjnych, stworzenia centralnego katalogu (bazy danych) materiałów bibliotecznych w formatach alternatywnych, uwzględniania przez twórców światowych i krajowych bibliotek cyfrowych, specyfiki tzw. programów lektorskich, powszechności nauczania i wykorzystywania w procesie edukacji systemu Braille'a i skrótów brajlowskich, nauczania odczytywania tyflografiki (rysunków wypukłych) i jej wykorzystywania w procesie edukacji, profesjonalizacji procesu wytwarzania tyflografiki

B. Mioduszewski, Fundacja „Aktywizacja”, Warszawa 2013; Społeczny Raport Alternatywny $z$ realizacji Konwencji o prawach osób z niepetnosprawnościami w Polsce, red. J. Zadrożny, Fundacja KSK, Warszawa 2015. 
i audiodeskrypcji, systematycznej, rozciągniętej w czasie technologicznej alfabetyzacji uczniów niepełnosprawnych wzrokowo, opartej na zintegrowaniu nauczania systemu Braille'a ( $w$ tym jego odmiany cyfrowej) z technologiami informacyjno-komunikacyjnymi.

Realizowane $\mathrm{w}$ obrębie tyflopedagogiki wycinkowe badania naukowo-aplikacyjne ${ }^{37}$ i badania pilotażowe ${ }^{38}$ - nie wyczerpują potrzeb badawczych $\mathrm{w}$ zakresie kultury informacyjnej i czytelniczej osób z niepełnosprawnością wzroku. Potwierdzają dobrze znane już z obserwacji i autopsji niebezpieczne tendencje. Niepokojące jest np. zjawisko niskiego poziomu kompetencji tyflopedagogicznych nauczycieli (nie tylko szkół ogólnodostępnych) w zakresie stosowania $\mathrm{w}$ procesie edukacji technik brajlowskich, tyflografiki, audiodeskrypcji i technologii wspomagających, co rzutuje na kompetencje informacyjne (kulturę informacyjną i czytelniczą) uczniów niepełnosprawnych wzrokowo.

Znamienna jest wyraźna przewaga umiejętności wykorzystywania nowych technologii przez młode osoby z niepełnosprawnością wzroku - nad umiejętnościami podstawowymi: samodzielne, bezpieczne poruszanie się, pełna samoobsługa, biegłe czytanie i poprawne ortograficznie pisanie, efektywne wykorzystanie tyflografiki.

Zwraca uwagę również stosunkowo duża wiedza osób z niepełnosprawnością wzroku odnośnie do skutecznego wykorzystania nowych technologii, a jednocześnie wraz ze wzrostem umiejętności efektywnego z nich korzystania - spadek umiejętności czytania i pisania ${ }^{39}$.

37 E. Śmiechowska-Petrovskij, Integrowanie technik brajlowskich i z zakresu technologii w edukacji uczniów z niepetnosprawnościa wzroku, [w:] Pismo Braille'a. Z tradycja w nowoczesność, red. M. Paplińska, Fundacja Polskich Niewidomych i Słabowidzących „Trakt”, Warszawa 2016, s. 101-125.

${ }^{38}$ M. Paplińska, Pismo Braille'a wobec wyzwań wspótczesnej komunikacji osób niewidomych - komunikat z badań, [w:] Pismo Braille'a. Z tradycji w nowoczesność, red. M. Paplińska, Fundacja Polskich Niewidomych i Słabowidzących „Trakt”, Warszawa 2016, s. 126-137.

$39 \mathrm{~J}$. Faherty, Proponents say the decline in braille instruction is leading $t$ illiteracy, “Braille Monitor" 2006, nr 9, s. 14-17; M. Paplińska, Niewidomy czytelnik - cyfrowy 
Wskazane wydają się zatem szerokie badania kultury informacji osób z niepełnosprawnością wzroku, uwzględniające kategorie badawcze proponowane przez M. Kisilowskąa ${ }^{40}$.

W ramach kategorii „świadomość informacyjna” (zdawanie sobie sprawy z istoty informacji, wielości i złożoności jej przejawów i procesów, którym podlega, zdolność umysłu do odzwierciedlania przestrzeni informacyjnej $w$ jej różnorodności i dynamice) istotne są np. kwestie: dostęp do edukacji, nowoczesnych technologii informacyjnych, produktów i usług informacyjnych, indywidualne granice poznawania przestrzeni informacyjnej (ilościowe, jakościowe).

W obrębie kategorii „aktywność informacyjna” (zachowania informacyjne człowieka lub podmiotu prawnego, ich zróżnicowanie i intensywność) ważny jest np. problem granicy między aktywnością a biernością informacyjną, kompetencji informacyjnych.

Kategoria „Przestrzeń informacyjna” zawiera trzy pola badawcze. Materialne fakty informacyjne (obiekty przestrzeni informacyjnej) obejmują nośniki informacji (wydawnictwa alternatywne) i urządzenia służące tworzeniu, przechowywaniu i udostępnianiu informacji (technologie informacyjno-komunikacyjne wraz $\mathrm{z}$ technologiami wspomagającymi/asystującymi).

Istotnym zagadnieniem jest tu kwestia udostępniania osobom niepełnosprawnym wzrokowo artefaktów potencjalnie materialnych, np.: teksty, obrazy różnego rodzaju, nagrania dźwiękowe i filmowe, bazy danych (bibliograficzne, pełnotekstowe, statystyczne itd.), katalogi bibliotek, serwisy informacyjne, portale i witryny internetowe.

Wśród artefaktów niematerialnych, najistotniejszym jest język. Przedmiotem badań winno tu być np. nowe słownictwo, tworzone

tubylec czy brajlowski analfabeta? O kryzysie umiejętności czytania dotykowego, [w:] Tyflopedagogika wobec wspótczesnej przestrzeni edukacyjno-rehabilitacyjnej, red. K. Czerwińska, M. Paplińska, M. Walkiewicz-Krutak, APS, Warszawa 2015, s. 179-195; M. Paplińska, Młode pokolenie osób z niepetnosprawnościa wzroku w paradoksie informacyjno-komunikacyjnym, [w:] Tyflopedagogika wobec współczesnej przestrzeni edukacyjno-rehabilitacyjnej, red. K. Czerwińska, M. Paplińska, M. Walkiewicz-Krutak, APS, Warszawa 2015, s. 136-155.

${ }^{40}$ M. Kisilowska, op. cit. 
w celu nazwania kolejnych produktów, usług czy narzędzi powstających w związku $\mathrm{z}$ zagospodarowywaniem przestrzeni informacyjnej osób niepełnosprawnych wzrokowo, zmiany w formach i konwencjach, jakie zachodzą w wyniku przemian dokonywanych w szerokim, społecznym i kulturowym wymiarze (postępująca skrótowość komunikatów, malejące znaczenie poprawności wypowiedzi, stosowanie emotikonów, demokratyzacja relacji na poziomie komunikacji pisemnej).

Szczególną wagę we wzmiankowanej koncepcji badawczej przypisuje się artefaktom behawioralnym, uwzględniającym m.in. takie zachowania niepełnosprawnych użytkowników informacji, jak: poszukiwanie informacji (poziom świadomości, zaangażowanie emocji, intensywność działań, dobór itd.), tworzenie informacji (zjawisko upubliczniania treści własnych z wykorzystaniem narzędzi 2.0), udostępnianie (upublicznianie) informacji rozmaitymi kanałami, na odpowiednich nośnikach, konkretnym odbiorcom bądź anonimowo, np. blogi, zwiększenie częstotliwości korzystania z różnych mediów w celu sprawdzenia „najnowszych” informacji - tzw. imperatyw informacyjny, zarządzanie informacją osobistą dla potrzeb prywatnych lub zawodowych - tzw. PIM, reakcje na informacje docierające do odbiorcy mimowolnie, estetyka i wizualizacja informacji, czyli zachowania związane $\mathrm{z}$ dbałością o wizualny kształt prezentowanych treści, np. infografika.

Należy mieć świadomość, że artefakty behawioralne oddziałują na przemiany życia społeczno-indywidualnego, takie jak: zmiany wzorca funkcjonowania w grupie (rodzinnej, rówieśniczej - indywidualizacja, izolacja, komunikacja mobilna i elektroniczna), wybrane aktywności życia codziennego (elektroniczna bankowość, zakupy internetowe), struktura produktów kultury. Przedmiotem zainteresowania winny tu być zasady regulujące funkcjonowanie osób z niepełnosprawnością wzroku w przestrzeni informacyjnej, a tym samym ich kulturę informacyjną, czyli cenione i przestrzegane wartości, normy regulujące zachowania oraz tradycje, zwyczaje i styl życia.

W świetle powyższego postuluje się zatem badania interdyscyplinarne nad kulturą informacji osób z niepełnosprawnością wzro- 
ku, stanowiące dyskurs: obywatelski, edukacyjny, translatoryjny, estetyczny ${ }^{41}$, którym przyświecać może pogląd Umberto Eco:

dzisiaj od człowieka kultury wymaga się znajomości zarówno książek, jak i nowych form pisania i gromadzenia informacji. Tylko tak można zagwarantować, że nowe media będą używane w sposób demokratyczny, bez odsuwania kogokolwiek od nowych zasobów informacji, tylko tak można uczyć każdego, jak wybierać i oceniać informacje, które otrzymuje ${ }^{42}$.

\section{Bibliografia}

Babik W., O natłoku informacji $i$ zwiazanym $z$ nim przeciążeniu informacyjnym, http://www.ktime.up.krakow.pl/ref2010/babik.pdf [dostęp: 31.04.2015].

Batorski D., Wykluczenie cyfrowe w Polsce, „Studia Biura Analiz Sejmowych Kancelarii Sejmu" 2009, nr 3(19).

Blak K., Internet a przyszłość książki. Rozważania z perspektywy cyfrowego tubylca, http://www.ktime.up.krakow.pl/symp2011/referaty2011/blak-l.pdf, s. 14 [dostęp: 31.04.2015].

Ciborowski M., Znaczenie audiodeskrypcji dla niewidomych w Polsce, „Przekładaniec” 2009, nr 20.

Czerwińska M., System Braille’a - rewolucja medialna czy inkluzja społeczna osób z niepetnosprawnością wzroku?, „Przegląd Biblioteczny” 2015, nr 3.

Czerwińska M., Niewidomy, [w:] Encyklopedia pedagogiczna XXI wieku, t. 3: M-O, red. T. Pilch, Wydawnictwo Akademickie "Żak”, Warszawa 2004.

Czerwińska M., System Braille'a w edukacji i rehabilitacji dzieci z niepetnosprawnościa wzroku - przyczynek do komunikacji i inkluzji społecznej, [w:] Edukacyjne oblicza komunikacji. Dyskurs interdyscyplinarny, red. J.J. Błeszyński, K.B. Kochan, Uniwersytet Zielonogórski, Zielona Góra 2016.

${ }^{41}$ E. Śmiechowska-Petrovskij, Kultura haptyczno-werbalna. Osoby niewidzace a sztuki wizualne - między doświadczeniem poznawczym i estetycznym, [w:] K. Krawiecka, E. Śmiechowska-Petrovskij, M. Żelazkowska, Sztuka/twórczość dostępna. Osoby $z$ niepetnosprawnościami i choroba psychiczna w kręgu recepcji i ekspresji sztuki, Wydawnictwo UKSW, Warszawa 2016, s. 57-126.

42 Za: K. Blak, Internet a przyszłość książki. Rozważania z perspektywy cyfrowego tubylca, http://www.ktime.up.krakow.pl/symp2011/referaty2011/blak-l.pdf, s. 14 [dostęp: 31.04.2015]. 
Faherty J., Proponents say the decline in braille instruction is leading tilliteracy, "Braille Monitor" 2006, nr 9, s. 14-17.

Gajda M., WCAG 2.0 w skrócie - 25 najważniejszych zasad, http:/ / dostepnestrony. pl/artykul/753 [dostęp: 21.11.2016]; Marcinkowski A., P. Marcinkowski, WCAG 2.0. Podręcznik dobrych praktyk, http://widzialni.org/wcag-20-pod recznik-dobrych-praktyk,m,mg,5,51 [dostęp 12.01.2015].

Ustawy o informatyzacji działalności podmiotów realizujących zadania publiczne, http://www.isap.sejm.gov.pl/Download?id=WDU20050640565\&type=3 [dostęp: 5.05.2017].

Główny Urząd Statystyczny, Społeczeństwo informacyjne w Polsce. Wyniki badań statystycznych z lat 2004-2006, Warszawa 2008, s. 7.

Grzegorzewska M., Wybór pism, PWN, Warszawa 1964.

http://www. fundacjakatarynka.pl/ [dostęp: 7. 05.2017].

http://www.audiodeskrypcja.org.pl/ [dostęp: 7.05.2017].

http://www.defacto.org.pl/ [dostęp: 7.05.2017].

http://www.kulturaslepych.farbb.com/ [dostęp: 7.05.2017].

Jakubowski M., Tyflografika - historia i wspótczesność, metody i technologie, „Tyfloświat” 2009, nr 1(3), http:/ / www.firr.org.pl/uploads/PUB/Tyfloswiat-01_2009.pdf [dostęp: 5.05.2017].

Jankowska A., Audiodeskrypcja - wzniosty cel w tłumaczeniu, „Między oryginałem a przekładem" 2009, R. XIV, s. 225-246.

Kalbarczyk M., Mirowski J., Świat opisywany dźwiękiem, Fundacja „Szansa dla Niewidomych", Warszawa 2015.

Kisilowska M., Kultura informacji, Wydawnictwo SBP, Warszawa 2016.

Konwencja Praw Osób Niepełnosprawnych, http://www.unic.un.org.pl/dokumen ty/Konwencja_Praw_Osob_Niepelnosprawnych.pdf [dostęp: 14.12.2016].

Krejtz K., Krejtz I., Szarkowska A., Kopacz A., Multimedia w edukacji. Potencjat audiodeskrypcji w kierowaniu uwaga wzrokowa ucznia, „Przekładaniec” 2014, nr 28.

Majewski T., Tyflopsychologia rozwojowa: Psychologia dzieci niewidomych i stabo widzacych, PZN, Warszawa 2002.

Melosik Z., Mass media, tożsamość i rekonstrukcje kultury wspótczesnej, [w:] Media Edukacja - Kultura, red. W. Skrzydlewski, S. Dylak, Polskie Towarzystwo Technologii i Mediów Edukacyjnych, Rzeszów - Poznań 2012.

Michalewicz I., Audiodeskrypcja po Euro 2012 - zawrotne tempo akcji czy para w gwizdek?, „Przekładaniec” 2014, nr 28.

Ministerstwo Polityki Społecznej, Zespół Zadaniowy ds. Reintegracji Społecznej, Narodowa Strategia Integracji Społecznej dla Polski, Warszawa 2004, http://www. mpips.gov.pl/userfiles/File/mps/NSIS.pdf, s. 23 [dostęp: 15.11.2016].

Nowe media w komunikacji społecznej XX w. Antologia, red. M. Hopfinger, Oficyna Naukowa, Warszawa 2005. 
Paplińska M., Młode pokolenie osób z niepetnosprawnościa wzroku w paradoksie informacyjno-komunikacyjnym, [w:] Tyflopedagogika wobec wspótczesnej przestrzeni edukacyjno-rehabilitacyjnej, red. K. Czerwińska, M. Paplińska, M. Walkiewicz-Krutak, APS, Warszawa 2015.

Paplińska M., Niewidomy czytelnik - cyfrowy tubylec czy brajlowski analfabeta? O kryzysie umiejętności czytania dotykowego, [w:] Tyflopedagogika wobec współczesnej przestrzeni edukacyjno-rehabilitacyjnej, red. K. Czerwińska, M. Paplińska, M. Walkiewicz-Krutak, APS, Warszawa 2015.

Paplińska M., Pismo Braille'a wobec wyzwań wspótczesnej komunikacji osób niewidomych - komunikat z badań, [w:] Pismo Brailléa. Z tradycji w nowoczesność, red. M. Paplińska, Fundacja Polskich Niewidomych i Słabowidzących „Trakt”, Warszawa 2016.

Paplińska M., Znaczenie czytania dotykowego i jego charakterystyka a bariery mentalne osób niewidomych i ociemniatych wobec pisma Braille'a, [w:] Pismo Braille'a. Z tradycją w nowoczesność, red. M. Paplińska, Fundacja Polskich Niewidomych i Słabowidzących „,Trakt”, Warszawa 2016.

Rezolucja Komisji ds. konstytucyjnych (AFCO) Parlamentu Europejskiego, http:// www.infor.pl/.../754032,Lepszy-dostep-do-ksiazek-i-prasy-dla-niewidomych-islabowidzacych.html [dostęp: 5.05.2017].

Rotberg I., W morzu informacji, http://www.psychologia-spoleczna.pl/porady/ 1506-w-morzu-informacji.html [dostęp: 15.01.2015].

Rozporządzenie Rady Ministrów z dnia 12 kwietnia 2012 r. w sprawie Krajowych Ram Interoperacyjności, minimalnych wymagań dla rejestrów publicznych i wymiany informacji w postaci elektronicznej oraz minimalnych wymagań dla systemów teleinformatycznych, http://www.isap.sejm.gov.pl/DetailsServlet?id= WDU20120000526 [dostęp: 5.05.2017].

Sadowska A., Audiodeskrypcja do ilustracji w prasie - wskazówki dla trenerów szkolacych audiodeskryptorów, „Przekładaniec” 2014, nr 28.

Społeczny Raport Alternatywny z realizacji Konwencji o prawach osób z niepetnosprawnościami w Polsce, red. J. Zadrożny, Fundacja KSK, Warszawa 2015.

Szarkowska A., Przekład audiowizualny w Polsce - perspektywy $i$ wyzwania, Przekładaniec 2009, nr 1(20).

Szymańska B., Strzymiński T., Audiodeskrypcja. Obraz słowem malowany. Standardy tworzenia audiodeskrypcji do produkcji audiowizualnych, Fundacja "Audiodeskrypcja", Białystok 2010.

Śmiechowska-Petrovskij E., Integrowanie technik brajlowskich $i$ z zakresu technologii w edukacji uczniów z niepetnosprawnościa wzroku, [w:] Pismo Braille'a. Z tradycja w nowoczesność, red. M. Paplińska, Fundacja Polskich Niewidomych i Słabowidzących „Trakt”, Warszawa 2016.

Śmiechowska-Petrovskij E., Integrowanie technologii $i$ technik brajlowskich w edukacji uczniów z niepetnosprawnością wzroku, [w:] Pismo Braille'a. Z tradycja w nowocze- 
sność, red. M. Paplińska, Fundacja Polskich Niewidomych i Słabowidzących „Trakt”, Warszawa 2016.

Śmiechowska-Petrovskij E., Kultura haptyczno-werbalna. Osoby niewidzace a sztuki wizualne - między doświadczeniem poznawczym i estetycznym, [w:] K. Krawiecka, E. Śmiechowska-Petrovskij, M. Żelazkowska, Sztuka/twórczość dostępna. Osoby $z$ niepetnosprawnościami i choroba psychiczna w kregu recepcji i ekspresji sztuki, Wydawnictwo UKSW, Warszawa 2016.

Tadeusiewicz R., Społeczność Internetu, Akademicka Oficyna Wydawnicza „Exit”, Warszawa 2002.

Traktat z Marrakeszu, http://www.prawoautorskie.gov.pl/.../Traktat_z_Marrakeszu _-_polska_wersja_jezykowa_finalna.pdf [dostęp: 5.05.2017].

Ustawa z dnia 25 marca 2011 r. o zmianie ustawy o radiofonii i telewizji oraz niektórych innych ustaw, http://www.isap.sejm.gov.pl/DetailsServlet?id=WDU2011 0850459

Walczak A., Rubaj M., Audiodeskrypcja na lekcji historii, biologii i fizyki w klasie uczniów $z$ dysfunkcja wzroku, „Przekładaniec” 2014, nr 28.

Więckowska E., Tyflografika - konieczność czasu, [w:] Środowisko Lasek w perspektywie historii i chrześcijańskiej myśli pedagogicznej, red. J. Placha, Wydaw. UKSW, Warszawa 2011.

Ustawa z dnia 29 grudnia 1992 r. o radiofonii i telewizji, http://www.isap.sejm. gov.pl/DetailsServlet?id=WDU19930070034 [dostęp: 5.05.2017].

Więckowska E., Zasady redagowania tyflografiki, „Tyfloświat” 2009, nr 3(5). http://www. firr.org.pl/uploads/PUB/Tyfloswiat-03_2009.pdf [dostęp: 5.05.2017].

Wykorzystanie technologii informacyjno-komunikacyjnych w aktywizacji osób niepetnosprawnych, red. B. Mioduszewski, Fundacja „Aktywizacja”, Warszawa 2013. 